TECHNICAL TRANSACTIONS 10/2017

CZASOPISMO TECHNICZNE 10/2017

ARCHITECTURE AND URBAN PLANNING

DOI: $10.4467 / 2353737$ XCT.17.165.7273

\author{
Katarzyna Hodor (katarzyna.hodor@pk.edu.pl) \\ Ewa Waryś \\ Institute of Landscape Architecture, Faculty of Architecture, Cracow University \\ of Technology
}

\title{
MODERN GREEN TECHNOLOGIES AND SOLUTIONS IN LANDSCAPE ARCHITECTURE
}

ZIELONE NOWOCZESNE TECHNOLOGIE I ROZWIĄZANIA

W ARCHITEKTURZE KRAJOBRAZU

\begin{abstract}
The paper presents modern technological solutions used in landscape architecture, with special emphasis on their occurrence in the areas of historical greenery. Dynamic introduction of new tools allows us to take special care of valuable areas, stressing their importance and at the same time granting them new functions. The latter part discusses a specific example of this type of solutions from the area of Katowice. These are modern developments that make the historic pattern of industrial city more legible.
\end{abstract}

Keywords: modern technologies, landscape architecture, Katowice

\section{Streszczenie}

W artykule przestawione zostaly rozwiązania nowoczesnych technologii stosowanych w architekturze krajobrazu ze szczególnym uwzględnieniem ich występowania na terenach zieleni historycznej. Dynamicznie wprowadzane nowe narzędzia pozwalają na objęcie szczególną dbałością te wartościowe obszary, podkreślając ich znaczenie równocześnie nadając nowe funkcje. W drugiej części omówiony zostanie szczególny przykład tego typu rozwiązań z terenu Katowic. Są to nowe realizacje uczytelniające historyczne układy miasta przemysłowego.

Słowa kluczowe: nowoczesne technologie, architektura krajobrazu, Katowice 


\section{New Technologies for areas of historic greenery}

In a consideration attempt of the occurrence of new technologies in areas of historic structured greenery we have to define the space that we relate our research to. It is the vast collection of human-shaped terrains, differentiated in their functions, forms, history and traditions. In urban areas these include parks, squares, alleys, and roadside greenery planted till $\mathrm{mid} 20^{\text {th }}$ century. The majority of these areas are protected, and works connected with them are mostly revalorizations, re-compositions and reconstructions. New tools are based on the development of new technologies that are linked to developments in different fields of science. These include: IT-development, access to the newest inventions and their synergy.

The changes occurring in technologies used in historic structured greenery can be divided in two groups. One of that serving the design process and the others applied in execution. New technologies used in design are of significant importance in conceptual considerations. They can substantially enrich the specialist research, broadening our knowledge of past of these locations. Archeological research based on computer tomography allow us to reveal e.g. relics of engineering structures, without interference with terrain. Botanical and palynological analyses connected with gathering information about preserved pollen in places that were not subject to soil replacement bring us the required knowledge of species composition that once grew in this area $[13$, p. 373]. Dendrological research allows for non-invasive determination of the condition of trees, measured with use of laser or ultrasound devices [1]. To this end portable devices are used, based on wireless communication. The biological surface monitoring is applied in case of vast spaces. A technology that links knowledge and concepts in a selected area that proves perfect for design are the Geographical Information Systems (GIS). These are integrated sets of an interface in form of a map, with spatial data databases. Numerical terrain models, 3D visualizations form a summary of application of computer technologies.

During execution stage methods based on innovativeness, ecology, and material engineering are implemented with use of advanced technologies [10, p. 146]. New solutions apply to use of water, light sources, different pavements and equipment elements.

Water has numerous values, other than just its aesthetic value, in historic greenery. When used appropriately it has important economic (protection of resources, health, condition of environment, microclimate of the city) and social roles. The systems for recycling of precipitation waters that are ever more frequently used allow to use them in an economical fashion. Watering networks grow in popularity, controlled with devices that are synchronized by measurements of soil condition and weather forecasts. Another function can be obtained by using water as a screen. This may be a temporary attraction in historic areas, during movie screenings or artistic events. We have sprinkling and gravitational screens that are commercially available. Depending on the type we can achieve laser and video images of different size. Sprinkling solutions require some 2 thousand liters of water per minute, and that is why they are usually installed on existing water reservoirs [18].

Introduction of lighting in the historic green areas frequently becomes an element that not only improves safety levels, but also shapes this space anew. From the beginning of $19^{\text {th }}$ century lighting became applied on a larger scale in public spaces, including parks and 
greeneries [11]. Illumination with use of gas, and later also electric lamps was used. The latter one was a technological revolution that allowed application of those solutions on larger scale. The current breakthrough in lighting are the lighting management systems that allow the use of rational control systems that adjust the light intensity depending on the time and traffic in public spaces and arteries. Solutions based on solar technologies with small wind turbines added are used in parks and squares. Mapping is another tool used in historic complexes. It is used for "light and sound" shows. It enables the visualization of artistic narratives, that can make historic gardens more attractive [8, p. 256]. The presented contents are diverse, and based on history of location, legendary characters, shows of space creators. Such solutions enrich the terrain with new meanings, contents, improving their aesthetics.

Pavements are a separate group of modern technologies in developments, and this can be divided onto several types: pro-ecological, ecological and safe [17]. These are used for construction of roads for vehicles and for pedestrians. Pro-ecological can be recycled and used again once their lifespan ends. Permeable path surfaces made of mineral breakstone are environmentally neutral and both visually and ecologically valuable. It is also worth to mentioned the pavement materials made of granulated recycled materials. They are abrasion resistant.

Equipment elements that are modern both in their form and materials used are utilized in historic greenery complexes. This group becomes growingly legible for its recipients, sometimes utilizing light, texture, shape and composition that become the signature of the respective location. The seats that connect greenery in form of parklets, pergolas in different forms, visual information systems that aid terrain orientation.

The concept of Smart cities is based on integrated watering, traffic management, parking, environmental monitoring, cleaning, and lighting systems and Wi-Fi zones. Numerous facilities for communities, not just the local ones, are based on technological innovations. This is integration and monitoring of public services and the visible participation of dwellers in managing the city. This type of solutions is ever more willingly introduced.

The aforesaid modern materials find their application in many cities that strive to improve the quality of life by connecting new technologies with tradition of place. The example of such an implication are the areas of Katowice, described in detail below.

\section{Modern solutions in the landscape of midtown Katowice}

\subsection{Location and development conditions of the analyzed area}

The history of Katowice as a town dates back to beginning of the $2^{\text {nd }}$ half of $19^{\text {th }}$ century. The oldest buildings were constructed in 1860s and 1870s. Together with the historic development of an area a transformation of the architectonic tissue occurred, from singleand two-storey houses and villas, to several storey high townhouses and palaces of the turn of $19^{\text {th }}$ and $20^{\text {th }}$ century $[9, \mathrm{p} .18]$. In the interwar period Katowice became the third centre of modern architectural thought in Poland (only after Warsaw and Gdynia). This period saw the construction of vast public buildings and residences [12, p. 79]. 
Scope of these considerations includes the area of the market and the nearby Katowice Culture Zone, located in the area of the former "Katowice" Coal Mine. The mine, once situated northwest of the market, operated till 1999. In the last years the area witnessed numerous construction works, as a part of revitalization program or a larger reconstruction program.

It is worth stressing that the discussed examples should not be directly qualified to group of historic structured greenery, due to the scarce number of plants that appeared in its historic development. Lack of greenery was the result of their functions such as communication node, market square and mine. These locations are still examples of important public spaces with representative (market) functions and preserved historic values. The conditions for development of both areas are mainly connected with the Silesian traditions, including the industrial origin of the place These formed an important spatial context and a point of reference in the design concepts. Proximity of $20^{\text {th }}$ century buildings, including objects with iconic status that became landmarks of that area also proved significant.

The Katowice market square was the first area to be analyzed and the oldest square in the city. It was the center of the former cottager's village of Katowice established in second half of $16^{\text {th }}$ century. In this place main communication routes also crossed, with residential buildings located along them. In the second half of $19^{\text {th }}$ century, as part of larger development plan for roads and buildings by German engineer - Heinrich A.M. Nottebohm the square was paved with cobblestone, surrounded with buildings and included in the urban composition of midtown Katowice [2, pp. 206-207]. This time witnessed numerous objects with large cultural value constructed on the sides of the square, bearing the idea artistic tendencies of the turn of $19^{\text {th }}$ and $20^{\text {th }}$ century. An example thereof is the building of the Silesian Theatre in the so called "near 1800 style", resembling the classicizing baroque [4, p. 192]. In its historic development the Katowice market square was frequently subject to considerations of architects and urban designers. Planning first changes occurred prior to 1939 and in the postwar period numerous plans for redevelopment were formed [2, p. 209]. Whole cultural heritage of the modernism age still plays an important role in city landscape, and similarly to the industrial objects influences the identity of the place.

The region of the today's Katowice Culture Zone is also of historic value. Due to its initial function as a mine area it is linked with genius loci (tradition of space). The Katowice Coal Mine (formerly Ferdinand) was one of the oldest industrial works in the city [3, p. 146]. The preserved mine buildings dating back to $19^{\text {th }}$ and $20^{\text {th }}$ century form an important part of the landscape, connected with history of this region and also one of the main design conditions. The other was the direct vicinity of iconic objects, including the Spodek Sport and Show Arena.

\subsection{Redevelopment of Katowice Market Square}

The redevelopment of Katowice market square started in 2012 and proceeded in stages. The Flower Square, located in southern part, was one of its important elements. In the initial stage of works the tramway rails that existed there, and the tarmac pavement were removed, the square was paved with granite. According to a design by the Redan design house of Szczecin a new spatial composition was introduce, based on regular system of trees and flower 
beds, surrounded by sitting places. Between them a marble fountain was constructed [16] (Fig. 1a). The greenery also appeared in the northern part of the market, where individual trees were planted, grass planted and pavements made of colorful tarmac introduced, due to the playground located in this part (Fig. 1b). Green walls located at the tramway rails (Fig. 1c) dorm an example of modern greenery forms in the market landscape. These act as an isolation, dividing the market square area and the noise and dust generated by vehicles, and also as a decoration - in form of intriguing composition of vertical gardens. They are first investment of this kind that was constructed in a public space on such a large scale [22].

Within the project, apart from pavement solutions and plants also water elements were introduced. Apart from the aforesaid miniature fountain in the Flower Square longitudinal water reservoirs were placed in the former trace of Rawa river, which today flows underneath the square surface (Fig. 1d). Wood-clad seats are located near the fountain and exotic plant species, brought in from the Gliwice town greenhouse, are placed there in the Summer. This composition is a direct reference to tradition of place, both by tracing the river, but also by continuing the tradition of collecting and displaying exotic plant specimens, that in Silesia dates back to the end of $19^{\text {th }}$ century. Throughout the summer period the surrounding of the artificial Rawa river enjoyed large interest both of local residents and tourists.
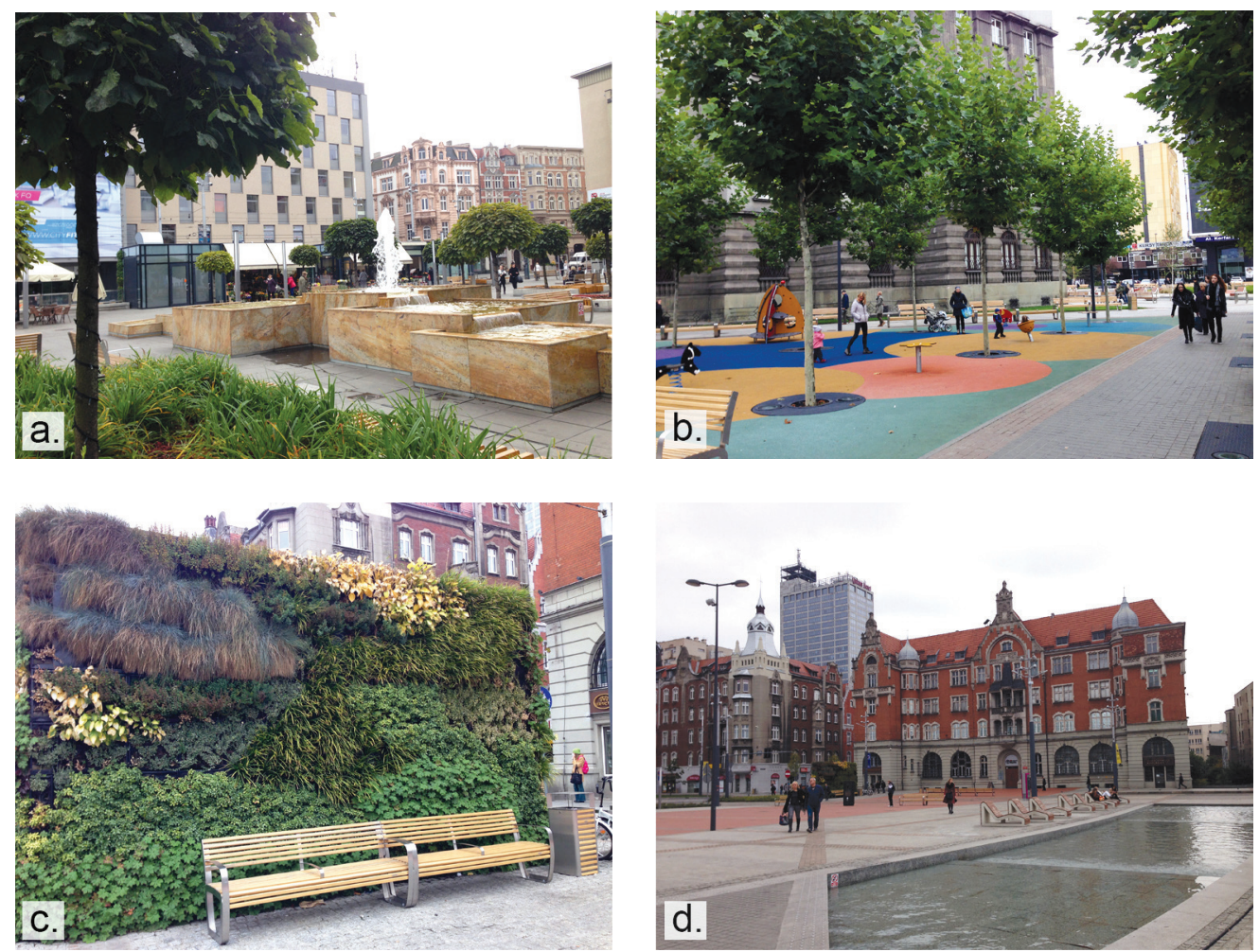

Fig. 1. a) marble fountain at the Flower Square, b) playground for children, c) fragment of the green wall (vertical garden), d) water fountain tracing the Rawa river (photo by E. Waryś, 2016) 
The modernization of architectural objects also contributed to the changes of the landscape of midtown Katowice. The contemporary transformation of existing buildings is one of the factors influencing the perception of urban interiors. The example of a late-modernist object on the side of the market, that was recently modernized is the former Silesian Press Hous, currently housing the City Council. Within the redevelopment the introduction of a completely new structure was envisaged. In the market square this included, among others, a glazed pavilion in modern form, located in the northern part.

\subsection{Katowice Culture Zone}

Modern approach to shaping greenery areas, with use of new materials and technologies and the concurrent recalling to the tradition of place is also visible in the Katowice Culture Zone that is located on the grounds of the former Katowice coal mine. This place, located to the east and southeast of the Katowice Spodek arena houses three objects integrated with greenery areas. Designs for all three buildings were selected in international architectonic design competitions. Today they form the most modern exhibition and conference complex in the region, directly neighboring with existing developments, including the solid of the Spodek arena, which due to its unique form had to be kept sufficiently exposed [15, p. 38].

The object located closest to the Spodek hall is the building of the International Congress Center, designed by JEMS Architekci studio and opened in March, 2015. This object is one of the most modern examples of connection of architecture and greenery and a novel recalling of the Silesian traditions. What is of symbolic dimension is, e.g. the black color of the façade, inspired by the coal mine that once existed in this place. This contrasts with the greens of the deformed roof, where a walking path was located, with seats, lighting and vista terraces $[15$, p. 38]. The intention of the architects was to construct a building on a landscape scale, divided by a garden canyon, linking the square at the Spodek arena with a historic path towards Bogucice district [19]. Introduction of walking paths, stairs made of black concrete, allowed the visitors to see the building and its vicinity from a new, changing perspective [14, p. 49]. Even if the solid of the building is to some degree reserved it utilizes many atypical construction systems, consisting of irregular shapes, girders and systems of ribs, that form the base of roof slab [7, p. 58]. Currently the object stands out in the city landscape, and at the same time forms background for preexisting buildings.

To the northeast of the congress centre the building of the National Symphonic Orchestra of the Polish Radio [NOSPR] is located, designed by the Kanior Studio of Katowice. In this case, along the brick solid of the building, which was moved to the southern border of its site on purpose, a public space with a traditional city scale was designed that is characterized by large amount of greenery. In front of the frontal façade a fountain was located that reflects the glyphs of window openings (Fig. 2.a). There is a concrete footbridge nearby, that leads towards the Spodek arena. To the northeast an amphitheatre was located, and isolated, wood-covered banks. To the north of the building a park was located with irregular plants 
grouped along the borders of the site. Both the object and also the space surrounding it are full of symbolic meanings and references to traditions of the region. The hornbeam labyrinth, located in the northeastern part, is an example - with its shape reflecting the urban fabric of the prewar design of midtown Katowice (Fig. 2.b). Also the building façade recalls the colors of Silesian worker's districts such as the Nikiszowiec of Katowice and the functional-spatial design is the reflection of design assumptions that are characteristic for modernist architecture [6, p. 46].
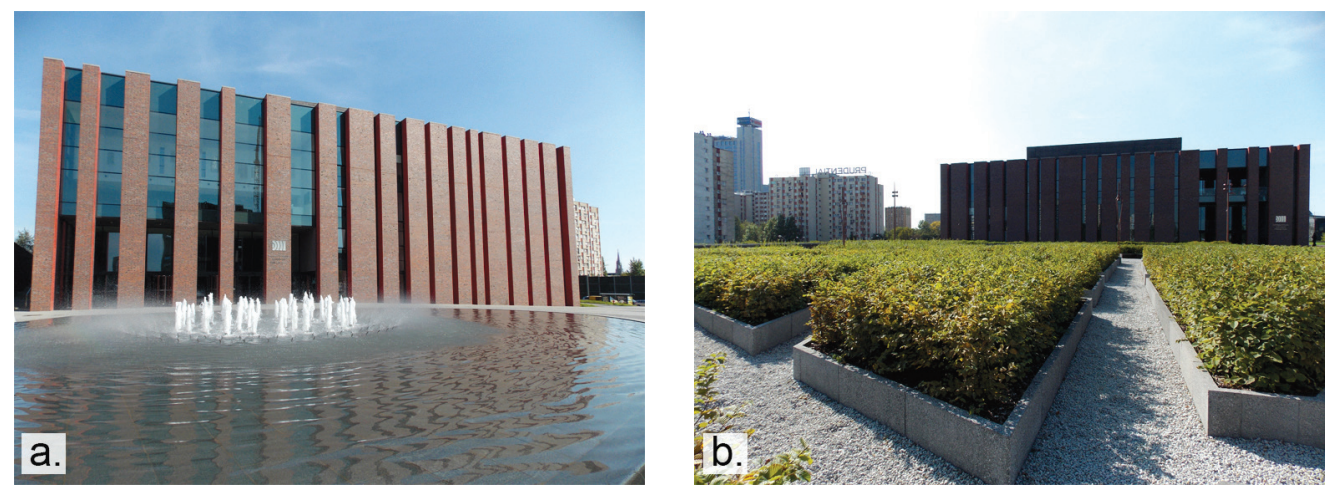

Fig. 2. a) fountain at the front façade of NOSPR, b) hornbeam labyrinth (photo by E. Waryś, 2015)

On the eastern side of the NOSPR the new seat of the Silesian Museum is located, designed by the Austrian Riegler Riewe Architekten studio of Graz. Pursuant to project assumptions the majority of exhibition spaces was located underground. There were glass boxes lighting the interiors and a surrounding park located at the surface. The new gardens were divided by a geometrical system of pathways, supplemented by decorative flower beds. The glass cubes visible on the surface follow the pastel colors of the gardens. Apart from the above the museum grounds also include preserved former mining objects, adopted to their modern functions. An example of that is the winding tower of the mining shaft, now turned in a vista point [21].

The developments located in the Katowice Culture Zone on numerous occasions met with both enthusiasm of local residents and architectural experts, and also with critic. The lack of a master plan for the whole area that would be based on reliable studies and pre-design analyses met with negative reactions. Even with zoning regulations in place for that area their assumptions were not included and the areas surrounding the respective buildings were designed by different designers. Another problems is also the competitive character of that area, as a result of gathering many cultural objects in one place [15, p. 39]. Another questions arose around the development of Katowice market square. An example of critic of the developments of the city was an artistic installation at the outflow of Rawa river, near the market square, with a neon-light reading "sundown". This installation was part of the Katowice Street Art Festival and its intention was to point viewers attention to the superficiality of the developments in Katowice 
and their sort of incredibility and artificiality [20]. Negative comments of this type, appearing with new investments, revealed the problems that were not solved to date, and the conflict areas that occurred in the public space. On the other hand the success of the completed investments is proved by constant interest demonstrated by residents and tourists and the large number of architectural prizes that the respective objects won.

\section{Summary}

Modernity of the investments discussed is demonstrated in materials, construction systems and functional solutions applied therein. The compositions that were introduced frequently departed from standard design schemes and opened towards the non-standard solutions. What is worth stressing from the viewpoint of rules for landscape design are the efforts to develop the space in the most effective manner and introduce diverse forms of designed greenery. Even using modern forms the designers of all projects aimed at preserving the identity of place and reached for inspirations from local traditions. The example of the discussed investments shows that introduction of designed greenery in design program allows for aestheticization and enhancement of attractiveness of city landscape.

\section{References}

[1] Bobek W., Assessing risks caused by trees in historic gardens and park areas, [in:] Threats occurring in historical gardens of countries in Central Europe: collective work, ed. K. Hodor, K. Łakomy, Politechnika Krakowska, Kraków 2016, 53-117.

[2] Bulsa M., Grzegorek G., Tabaczyński P., Waniek H., Ulice i place Katowic, Prasa i Książka, Katowice 2012.

[3] Franta J., Rewitalizacja obszarów poprzemystowych - dwa przykłady - jedno podejście, Czasopismo Techniczne, 3-A/2012, 145-150.

[4] Kozina I., Rozwój miast przemystowych, [in:] Sztuka Górnego Śląska od średniowiecza do końca XX wieku, ed. E. Chojecka, Muzeum Śląskie, Katowice 2004, 182-194.

[5] Lynch K., Obraz miasta, Archivolta, Kraków 2010.

[6] Mycielski K., Bogactwo odniesień, „Architektura Murator”, ZPR Media, 12/2014, 46.

[7] Pachowski P., Zielona Dolina, „Architektura Murator”, ZPR Media, 08/2015, 58.

[8] Siewniak M., Mitkowska A., Tezaurys sztuki ogrodowej, 130, 256.

[9] Szaraniec K., Szaraniec L., Katowice: przewodnik, Wojewódzkie Przedsiębiorstwo Usług Turystycznych, Katowice 1980.

[10] Wines J., Zielona Architektura, Taschen 2008.

[11] Wlazło-Malinowska K., Light as an tool shaping city's nightscape.

[12] Wojewódzki Program Opieki nad Zabytkami w Województwie Śląskim na lata 2014-2017, opracowanie wykonane przez Śląskie Centrum Dziedzictwa Kulturowego w Katowicach, Katowice 2014. 
[13] Zachariasz A., Projektowanie ogrodów historycznych. Przypadki krakowskie, „Czasopismo Techniczne" 2-A/1/20011, 367-373.

[14] Zagała Ł., Śląskie nieprzegadane i szanujące kontekst, „Architektura Murator”, ZPR Media, 08/2015, 48-49.

[15] Żylski T., Historia MCK, „Architektura Murator”, ZPR Media, 08/2015, 38-39.

[16] http://www.bryla.pl (accessed: 04.09.2017).

[17] http://edroga.pl/drogi-i-mosty/lampy-stosowane-w-oswietleniu-ulicznym-zeszczegolnym-uwzglednieniem-zrodel-led-cz-iii-09055829 (accessed: 04.09.2017).

[18] http://www.ekranywodne.pl/posejdon/ (accessed: 04.09.2017).

[19] http://jems.pl (accessed: 04.09.2017).

[20] http://magazynszum.pl (accessed: 04.09.2017).

[21] http://www.muzeumslaskie.pl (accessed: 04.09.2017).

[22] http://www.zielonesciany.pl (accessed: 04.09.2017). 